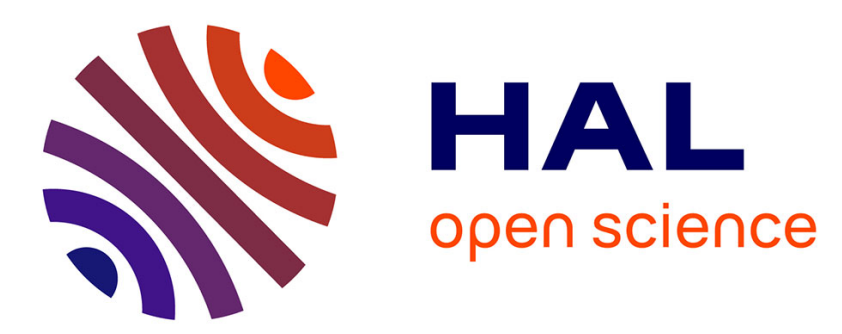

\title{
Niobium- and antimony-doped tin dioxide aerogels as new catalyst supports for PEM fuel cells \\ Guillaume Ozouf, Christian Beauger
}

\section{To cite this version:}

Guillaume Ozouf, Christian Beauger. Niobium- and antimony-doped tin dioxide aerogels as new catalyst supports for PEM fuel cells. Journal of Materials Science, 2016, 51 (11), pp.5305-5320. 10.1007/s10853-016-9833-7 . hal-01280119

HAL Id: hal-01280119

https://hal-mines-paristech.archives-ouvertes.fr/hal-01280119

Submitted on 29 Feb 2016

HAL is a multi-disciplinary open access archive for the deposit and dissemination of scientific research documents, whether they are published or not. The documents may come from teaching and research institutions in France or abroad, or from public or private research centers.
L'archive ouverte pluridisciplinaire HAL, est destinée au dépôt et à la diffusion de documents scientifiques de niveau recherche, publiés ou non, émanant des établissements d'enseignement et de recherche français ou étrangers, des laboratoires publics ou privés. 


\title{
Niobium- and antimony-doped tin dioxide aerogels as new catalyst supports for PEM fuel cells
}

\author{
G. Ozouf, C. Beauger*
}

MINES ParisTech, PSL Research University, PERSEE - Centre procédés, énergies renouvelables et systèmes énergétiques, CS 10207 rue Claude Daunesse 06904 Sophia Antipolis Cedex, France

*corresponding author

Keywords: Tin dioxide, aerogel, $\mathrm{Nb}$ and $\mathrm{Sb}$ doping, catalyst support, Fuel cells.

\begin{abstract}
In order to tackle the problem of low durability, tin dioxide was studied to replace carbon black as a catalyst support in Proton Exchange Membrane Fuel Cells (PEMFCs). $\mathrm{SnO}_{2}$ is a well-known n-type semi-conductor whose electronic conductivity can be improved by doping with hypervalent cations such as $\mathrm{Nb}^{5+}$ or $\mathrm{Sb}^{5+}$. In addition, as a catalyst support, this material has to develop a high specific surface area with an adequate mesoporous morphology to allow both good dispersion and activity of the catalyst (Pt). To this end, our objective was to develop doped $\mathrm{SnO}_{2}$ aerogels in order to gather in a same material both a high electronic conductivity and an adapted morphology. In this study $\mathrm{SnO}_{2}$ xerogels and aerogels were successfully synthetized following an acid-catalyzed sol-gel route starting with metal alkoxides as precursors. Dried gels were calcined for $5 \mathrm{~h}$ at $600{ }^{\circ} \mathrm{C}$ in flowing air. The effect on both the structure and the morphology of the material resulting from doping with niobium or antimony was investigated by XRD, SEM and nitrogen sorption. The electronic conductivity of pure and doped $\mathrm{SnO}_{2}$ materials was obtained from impedance spectroscopy and resistance measurements. Our materials showed a very interesting airy morphology adapted for the foreseen application: a reasonable specific surface area $\left(80-90 \mathrm{~m}^{2} / \mathrm{g}\right)$ with a bimodal pore size distribution centered on around $25 \mathrm{~nm}$ and $45 \mathrm{~nm}$. Moreover, all Sb-doped samples exhibited significant improvement in electronic conductivity. 5 at.\% Sb-doped $\mathrm{SnO}_{2}$ even showed an electronic conductivity of $1 \mathrm{~S} / \mathrm{cm}$, very similar to that of Vulcan XC-72 (4 $\mathrm{S} / \mathrm{cm}$ ) and representing a 5 orders of magnitude increase compared to that of pure $\mathrm{SnO}_{2}$.
\end{abstract}




\section{Introduction}

Fuel cells are environmentally friendly electrochemical energy converters that produce electricity and heat mainly from hydrogen and air [1-3]. Among the many existing types of fuel cells, Proton Exchange Membrane Fuel Cells (PEMFCs) have the advantage of providing a large range of power, from a few W to hundreds of $\mathrm{kW}$. Operating at low temperatures $\left(80^{\circ} \mathrm{C}\right)$, PEMFCs allow quick starts what makes them particularly interesting for transport applications. Low temperature operation limits the choice of catalysts for electrochemical reactions $\left(\mathrm{H}_{2}\right.$ oxidation, $\mathrm{HOR}$ and $\mathrm{O}_{2}$ reduction, ORR) to noble metals, mostly platinum. To reduce the amount of platinum while maintaining good performance, platinum nanoparticles are dispersed on a support. Because they have both a high electronic conductivity and a high specific surface area (respectively about $4 \mathrm{~S} / \mathrm{cm}$ and $254 \mathrm{~m}^{2} / \mathrm{g}$ for Vulcan XC-72 [4]), current electrocatalysts are based on carbon blacks (Vulcan XC-72R or TKK TEC10E40E for instance). However, the corrosion of carbon black on the cathode side in fuel-cell operating conditions $(\mathrm{E}=$ $1.2 \mathrm{~V}, \mathrm{~T}=80{ }^{\circ} \mathrm{C}$, high relative humidity and strongly acidic environment) is responsible for contact losses between the conductive carbon support and the catalyst, thus limiting the durability of PEMFC. This phenomenon is particularly marked for transport applications, during start / stop cycles $[4,5]$. They may indeed cause a reverse current compared to the normal operation of the fuel cell, leading to an increase in the cathode potential of up to $1.44 \mathrm{~V}$. In the presence of platinum nanoparticles, such high potential causes severe corrosion of the cathode following the reaction:

$$
\mathrm{C}+2 \mathrm{H}_{2} \mathrm{O} \rightarrow \mathrm{CO}_{2}+4 \mathrm{H}^{+}+4 \mathrm{e}^{-} \quad \mathrm{E}^{0}=0.207 \mathrm{~V} \text { versus NHE }
$$

Degradation mechanisms include dissolution as well as coalescence of platinum particles, thus limiting their activity [6].

According to thermodynamic calculations derived from Pourbaix $\mathrm{pH}$-potential diagrams, tin dioxide is expected to be very stable in PEMFC operating conditions. Its utilization as a catalyst support should improve PEMFC durability [7]. Tin dioxide is an n-type semi-conductor $(\mathrm{Eg}=3.6 \mathrm{eV})$. Doping $\mathrm{SnO}_{2}$ with hypervalent donor components like $\mathrm{Nb}^{5+}$ or $\mathrm{Sb}^{5+}$ leads to a significant increase of the electronic conductivity [8, 9]. Due to its remarkable bulk and surface properties, this material is already used as a transparent conductive oxide (TCO) [10], an electrode material in Li-ion batteries [11, 12], a catalyst for oxidation reaction [13-15] and a sensing material in gas sensors [16-18].

Several authors have shown that using pure $\mathrm{SnO}_{2}$ as a catalyst support effectively improves the durability of PEMFC, mostly thanks to improved corrosion resistance [19-21]. Moreover, it reduces polymer membrane 
degradation by neutralizing the formation of $\mathrm{H}_{2} \mathrm{O}_{2}$ formed during ORR [22]. It also allows better tolerance to CO than Pt / C electrocatalysts [14, 23, 24]. This can be explained by the oxidation of CO adsorbed at the Pt surface by the hydroxyl groups covering the surface of $\mathrm{SnO}_{2}$ [25]. However, electrochemical characteristics, like the electrochemical surface area (ECSA) or the oxygen reduction reaction (ORR) mass and specific activities of $\mathrm{Pt} / \mathrm{SnO}_{2}$ electrocatalysts, are relatively low compared to those of $\mathrm{Pt} / \mathrm{C}$, mostly due to their poor electronic conductivity and low specific surface area. Recent studies have shown the potential of doping $\mathrm{SnO}_{2}$ by $\mathrm{Nb}^{5+}[26-$ 29] or $\mathrm{Sb}^{5+}[26,27,30-36]$. In addition to improving electronic conductivity, dopants are known to inhibit particle growth [37] and modify the material's morphology. Although improvements have been observed compared to pure $\mathrm{SnO}_{2}$, experimental results generally show lower performance than carbon black, particularly regarding mass catalytic activity. In some cases, depending on the $\mathrm{SnO}_{2}$ morphology, mass catalytic activities were improved, even surpassing those of Pt/C electrocatalysts [27, 35]. This has been ascribed to the sometimes contested strong metal-support interaction (SMSI) [38, 39]. It has been proposed that this strong interactions between $\mathrm{SnO}_{2}$ and $\mathrm{Pt}$ may change the Pt electronic structure and lower the activation barrier for oxygen dissociation [40]. However a recent study has shown that steric effects are more likely the cause of this lower activation barrier [41].

The morphology of the support is primordial to limit concentration polarization and ease fluids management in volume electrode. Aerogels are to this end particularly interesting materials. Carbon aerogels have already proven their ability to efficiently support catalysts for PEMFC application [42, 43]. Their morphology can be adjusted by playing on the sol-gel parameters for higher specific surface areas with adequate mesoporosity.

In this study, $\mathrm{SnO}_{2}$ aerogels were thus synthesized to be used as a catalyst support for PEMFC in order to overcome the reported limitations regarding morphology and durability. The effect of doping $\mathrm{SnO}_{2}$ with niobium or antimony on the electronic conductivity as well as on the morphology has also been investigated.

\section{Experimental}

$\mathrm{SnO}_{2}$ synthesis route

Metal oxides were synthesized following a sol-gel route, starting with metal alkoxide precursors: $\operatorname{Sn}(\mathrm{OiPr})_{4}$, $\mathrm{Nb}(\mathrm{OiPr})_{5}$ and $\mathrm{Sb}(\mathrm{OiPr})_{3}$ all purchased from Alfa Aesar. Two solutions (A \& B) were prepared. Solution A, consisting of tin isopropoxide in isopropanol (Acros Organics, 99.5\%) with a corresponding amount of the doping element, was placed under magnetic stirring. Solution B, consisting of nitric acid (Alfa Aesar, 2N) 
$\left(\mathrm{HNO}_{3} / \mathrm{Sn}=0.072 \mathrm{~mol} / \mathrm{mol}\right)$ in water $\left(\mathrm{H}_{2} \mathrm{O} / \mathrm{Sn}=3.06 \mathrm{~mol} / \mathrm{mol}\right)$ and isopropanol $(\mathrm{iPrOH} / \mathrm{Sn}=119 \mathrm{~mol} / \mathrm{mol})$, was also mixed under magnetic stirring. Solution B was then slowly dripped into solution A and a gel formed after a few minutes. The gel was then covered with isopropanol to prevent any drying and aged for 48 hours at room temperature before being washed with isopropanol three times a day for two days. After washing, the resulting gels were dried either by conventional evaporation to obtain xerogels, or under $\mathrm{CO}_{2}$ in supercritical conditions $\left(80\right.$ bars, $40^{\circ} \mathrm{C}$ ) to obtain aerogels. The resulting solids were heat treated under air for $5 \mathrm{~h}$.

After calcination, the sample color turned blue or black respectively for $\mathrm{SnO}_{2}$ : $\mathrm{Sb}$ aerogels or xerogels. The $\mathrm{SnO}_{2}: \mathrm{Nb}$ xerogels turned light green whereas the $\mathrm{SnO}_{2}: \mathrm{Nb}$ aerogels remained white. Compared to aerogels, xerogels are likely to be darker in color due to a higher density resulting from the drying route.

Samples were labeled according to a dedicated nomenclature. For example, the $\mathrm{SnO}_{2}: \mathrm{Nb}(10$ at.\%) aerogel sample is labeled A6SN100, where A stands for aerogel ( $\mathrm{X}$ for xerogels), 6 for calcination at $600{ }^{\circ} \mathrm{C}$ in air, $\mathrm{S}$ for $\mathrm{SnO}_{2}, \mathrm{~N}$ for $\mathrm{Nb}$ dopant ( $\mathrm{S}$ for $\mathrm{Sb}$ ) and 100 for 10 at.\% doping.

\section{Characterization}

XRD measurements were performed using an X'Pert pro, Philips diffractometer ( $\mathrm{Cu}$ K $\alpha$ of $\lambda=1.5405 \AA$ ). The diffractometer was operated at $45 \mathrm{kV}$ and $30 \mathrm{~mA}$. Data were collected at steps of $0.05^{\circ}$ from $20^{\circ}$ to $90^{\circ}$ in $2-\theta$ mode with a Pixcel counter.

Morphologies were analyzed by SEM using a Supra 40 with Gemini column operated at $3.00 \mathrm{kV}$. The oxide powders were deposited on adhesive conducting carbon tapes and coated with a $7 \mathrm{~nm}$ thick platinum layer, using a Quorum (Q150 T).

In addition, nitrogen sorption analysis was performed with a Micromeritics ASAP 2020. Samples were first degassed for $120 \mathrm{~min}$ at $100{ }^{\circ} \mathrm{C}$ and $10 \mu \mathrm{mHg}$. The Brunauer-Emmett-Teller (BET) model was applied to determine the specific surface area. The pore size distributions were calculated applying the Barret-JoynerHalenda $(\mathrm{BJH})$ method to the desorption branch of the isotherms. The assessments of microporosity were made from t-plot construction using the Harkins-Jura correlation.

Concerning the pore size distribution determination using this technique, we assumed that the samples were mechanically strong enough after calcination to withstand the pressure applied during the experiment. 
The bulk chemical composition was analyzed by Energy Dispersive X-ray Spectroscopy (EDX) performed during SEM observation with a Philips XL30 operated at $15 \mathrm{kV}$.

The surface chemical composition was analyzed by X-ray Photoelectron Spectroscopy (XPS) using a Thermo Scientific K-Alpha system. The spectrometer was equipped with an AlKa monochromated source and a low energy flood-gun for charge compensation.

The ellipsoid spot size is about $350 \mu \mathrm{m} \times 700 \mu \mathrm{m}$.

The electronic conductivity was investigated by impedance spectroscopy and direct resistance measurements.

For impedance spectroscopy, the frequency ranged from $100 \mathrm{~Hz}$ to $1 \mathrm{MHz}$ with a potential of $200 \mathrm{mV}$ and an amplitude of $100 \mathrm{mV}$. Since pellet formation was difficult for $\mathrm{SnO}_{2}$ samples, impedance spectroscopy measurements were only performed on xerogel sample parts. Due to their powder form, it was actually not possible to perform impedance spectroscopy measurements on aerogels. Next, a homemade conductivity cell was developed, made up of two copper electrodes $\left(S=0,785 \mathrm{~cm}^{2}\right)$ surrounded with a Teflon ring. Samples were introduced between these two electrodes (see Fig. 1). A potentiostat was used to apply a current of $105 \mathrm{~mA},-105$ $\mathrm{mA}$ or $400 \mathrm{~mA}$ and the voltage was measured for each current. The homemade conductivity cell was placed in a press and measurements were made at room temperature, without and with pressure at $500 \mathrm{~kg}$ and $1000 \mathrm{~kg}$ (respectively $6.5 \times 10^{2} \mathrm{~kg} / \mathrm{cm}^{2}$ and $13 \times 10^{2} \mathrm{~kg} / \mathrm{cm}^{2}$ ).

The conductivity $(\sigma)$ was calculated with the formula $\sigma=\mathrm{e} /\left(\mathrm{R} \times \mathrm{S}_{\text {electrode }}\right)$, where e is the thickness of the sample, $\mathrm{R}$ the measured resistance and $\mathrm{S}_{\text {electrode }}$ the surface of the electrode.
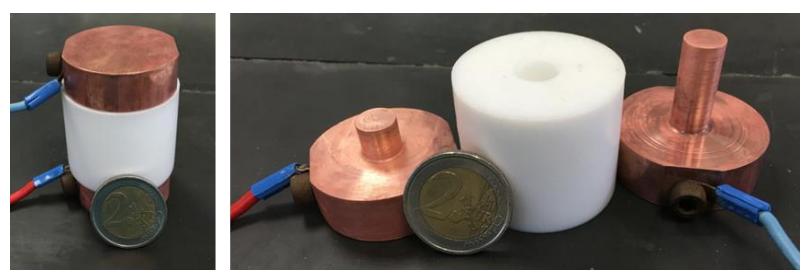

Fig 1 Homemade conductivity cell picture assembled (left) and disassembled (right) 


\section{Results and discussion}

\section{Structural and morphological characterization}

In this section, we present the structural and morphological characterization results. These results highlight specific properties such as crystallinity and specific surface areas or pore size distributions, which are crucial in selecting the most appropriate sample for the foreseen application.

Since the electronic conductivity in semi-conductors is strongly related to the periodic crystal structure, materials were calcined at different temperatures in air. The resulting XRD diagrams are shown in Fig. 2.

All calcined samples show characteristic peaks of rutile $\mathrm{SnO}_{2}$. After calcination at $400^{\circ} \mathrm{C}$, the XRD peaks are relatively wide with very weak intensity, showing low crystallinity, with the material remaining partially amorphous. The crystallinity improves following calcination at $700^{\circ} \mathrm{C}$. $\mathrm{SnO}_{2}$ xerogels then exhibit good crystallinity, the peaks are intense and the Full Width at Half Maximum is small. Both the electronic conductivity and the specific surface area are important for catalyst support. Given that the higher the calcination temperature the better the crystallinity but the lower the specific surface area, we needed to find a compromise. In order to avoid too severe a decrease in the specific surface area, materials were calcined at $600^{\circ} \mathrm{C}$.

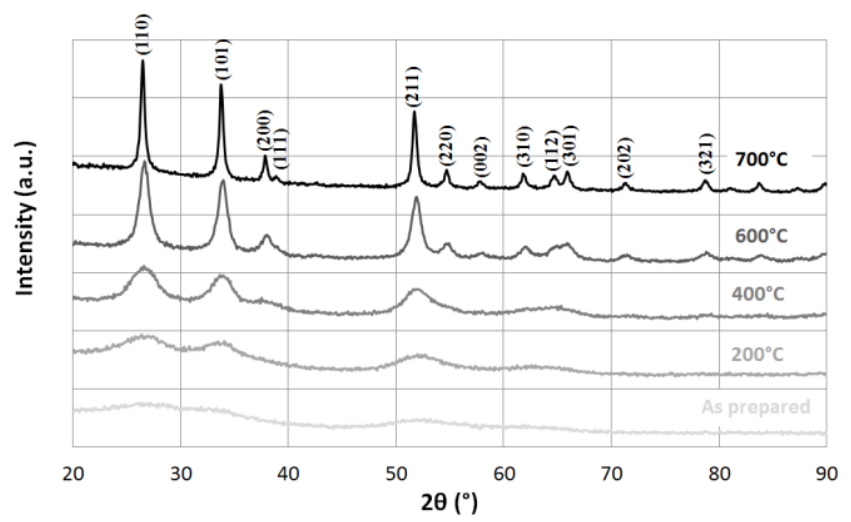

Fig. $2 \mathrm{X}$ ray diffraction diagrams of pure $\mathrm{SnO}_{2}$ xerogels before and after calcination at $200^{\circ} \mathrm{C}, 400^{\circ} \mathrm{C}, 600^{\circ} \mathrm{C}$ and $700^{\circ} \mathrm{C}$ for $5 \mathrm{~h}$ in air

$\mathrm{Nb}$ and $\mathrm{Sb}$ Doped $\mathrm{SnO}_{2}$ samples were prepared following a similar synthesis route, simply adding the dopant precursor to the alkoxide solution. Samples were calcined in air for $5 \mathrm{~h}$ at $600{ }^{\circ} \mathrm{C}$. 
Whatever the amount of dopant between 5 and 15 at.\%, XRD diffractograms of doped $\mathrm{SnO}_{2}$ aerogels also only showed the characteristic peaks of the $\mathrm{SnO}_{2}$ rutile phase (see Fig. 3 for pure and 10 at\% doped samples). No new crystal phase was detected and we observed a peak shift over a smaller angle. This shift is more pronounced for Sb-doped samples than for Nb-doped ones (insert in Fig. 3), resulting from a greater modification of the $\mathrm{SnO}_{2}$ lattice parameters. Both the absence of a new phase and the observation of XRD peak shifts are good indications of proper doping.

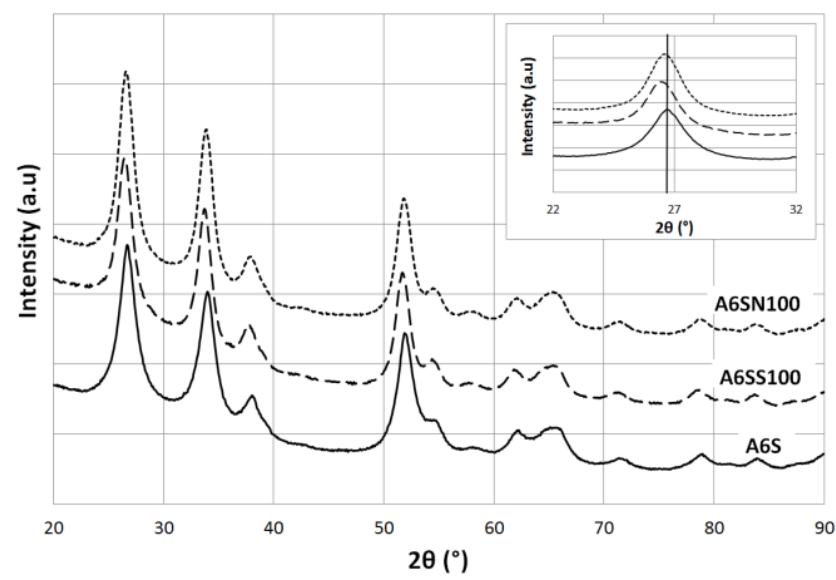

Fig. $3 \mathrm{X}$ ray diffractogram of aerogels: pure $\mathrm{SnO}_{2}(\mathrm{~A} 6 \mathrm{~S}), \mathrm{SnO}_{2}: \mathrm{Sb}\left(10\right.$ at.\%) (A6SS100) and $\mathrm{SnO}_{2}: \mathrm{Nb}(10$ at.\%) (A6SN100). All samples were calcined for $5 \mathrm{~h}$ at $600^{\circ} \mathrm{C}$ in air

SEM analyses of the samples calcined at $600{ }^{\circ} \mathrm{C}$ were then performed to visualize the morphology of the aerogels and xerogels (Fig. 4 and 5) and possibly check the impact of doping.

The morphology of pure $\mathrm{SnO}_{2}$ aerogel (A6S) results from the agglomeration or aggregation of rather small particles (about $13 \mathrm{~nm}$ ). The organization of such agglomerates results in the formation of large pores.

Doping seems to inhibit particle growth during the sol-gel process. Nb- or Sb-doped aerogels are indeed made up of smaller particles than pure $\mathrm{SnO}_{2}$ aerogels. Nucleation and growth control of $\mathrm{SnO}_{2}$ particles with dopant has already been observed and reported $[9,28,37]$.

The overall picture of $\mathrm{Nb}$-doped $\mathrm{SnO}_{2}$ aerogel (A6SN100) is quite similar to that of pure $\mathrm{SnO}_{2}(\mathrm{~A} 6 \mathrm{~S})$ although the agglomerates look slightly smaller. 

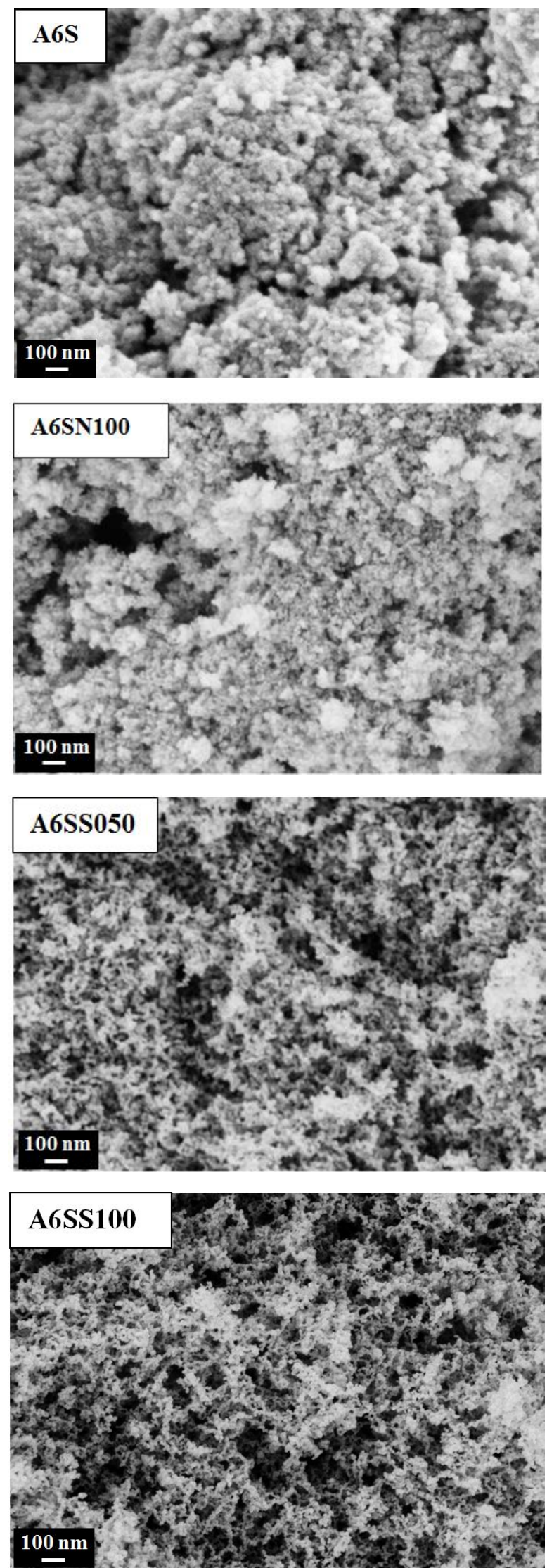

Fig. 4 SEM pictures of aerogels: pure $\mathrm{SnO}_{2}(\mathrm{~A} 6 \mathrm{~S}), \mathrm{SnO}_{2}: \mathrm{Nb}$ (10 at.\%) (A6SN100), $\mathrm{SnO}_{2}: \mathrm{Sb}$ (5 at.\%) (A6SS050) and $\mathrm{SnO}_{2}: \mathrm{Sb}\left(10\right.$ at.\%) (A6SS100) (All samples calcined for $5 \mathrm{~h}$ at $600{ }^{\circ} \mathrm{C}$ in air) 
On the contrary, the morphology of Sb-doped $\mathrm{SnO}_{2}$ aerogels (A6SS050 and A6SS100) is significantly different. They show a very interesting airy morphology lying on a three-dimensional network made up of interconnected particles. It is noteworthy that this morphology is quite similar to that of carbon aerogels previously synthesized in our group [43]. $\mathrm{Sb}$ doped $\mathrm{SnO}_{2}$ aerogels are from this point of view more interesting than $\mathrm{Nb}$ doped ones.

As expected from the drying route, xerogel samples showed a very different morphology. X6SS050 and X6SS100, presented in Fig. 5, are much denser and show less apparent porosity than their aerogel counterparts.
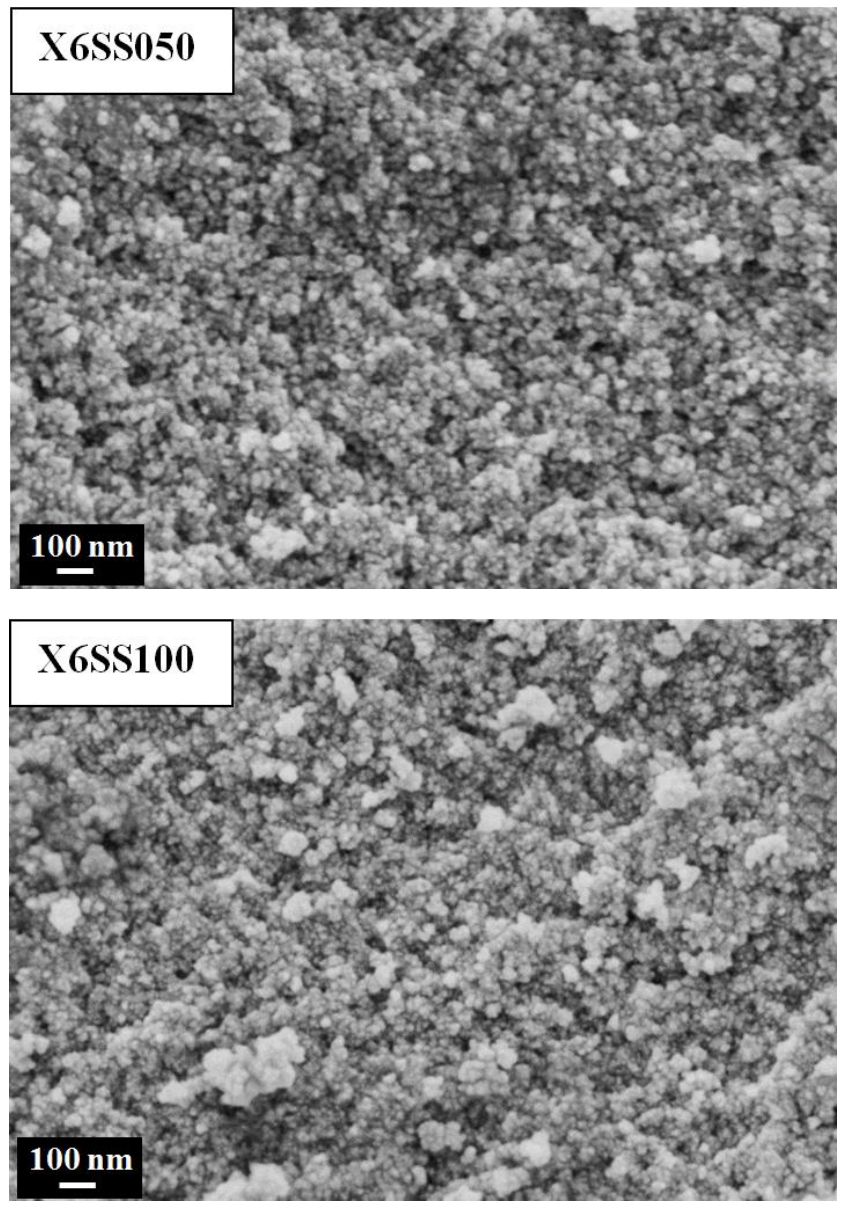

Fig. 5 SEM pictures of xerogels: $\mathrm{SnO}_{2}: \mathrm{Sb}\left(5\right.$ at.\%) (X6SS050) and $\mathrm{SnO}_{2}: \mathrm{Sb}$ (10 at.\%) (X6SS100). All samples calcined for $5 \mathrm{~h}$ at $600{ }^{\circ} \mathrm{C}$ in air

To obtain additional morphological data, we performed nitrogen sorption analysis. The results are reported in Table 1 and Fig. 6 for aerogels and in Table 2 and Fig. 7 for xerogels.

First of all, the type-IV isotherms obtained are representative of mesoporous materials. 
Specific surface areas were calculated based on the BET model. Pore size distributions and mesoporous volumes were calculated based on the BJH model, assuming that all calcined samples are mechanically strong enough to withstand applied forces during analysis.

It is interesting to note that the doping rate impacts both the specific surface area and the mesoporous volume. A maximum was observed for 10 at.\% doping rate. Values are actually relatively high for pure and 10 at. $\%$ doped materials, reaching almost $90 \mathrm{~m}^{2} / \mathrm{g}$ for the specific surface area, and $0.3 \mathrm{~cm}^{3} / \mathrm{g}$ for the mesoporous volume, whatever the dopant used ( $\mathrm{Sb}$ or $\mathrm{Nb})$.

The microporous volume of aerogel samples is negligible compared to their mesoporous volume. This is of utmost importance for the foreseen application, since most of the porosity will thus be accessible for Pt deposition and utilization. Here again, Sb-doped aerogels are more promising than pure or Nb-doped ones, showing an even smaller microporous volume.

The pore size distribution, calculated using the $\mathrm{BJH}$ method from isotherms, shows, for pure $\mathrm{SnO}_{2}$ aerogels, a multimodal distribution with quite a narrow peak at around $15 \mathrm{~nm}$ and broader ones centered on 20 and $40 \mathrm{~nm}$ (Fig. 6).

Looking at Fig. 6, $\mathrm{N}_{2}$ sorption should be complemented by mercury porosimetry analysis to fully characterize the pore size distribution, especially in the macroporous domain. Due to the nature of the samples, such an analysis could not be performed. Still, $\mathrm{N}_{2}$ sorption analysis allowed to highlight morphology differences between aerogels samples.

The pore size distribution observed for doped samples is notably modified. First, the main peaks at 15, 20 and 40 nm observed for pure $\mathrm{SnO}_{2}$ have shifted to larger diameters, namely 20, 30 and $45 \mathrm{~nm}$. Second, the contributions at 30 and $45 \mathrm{~nm}$ are significantly lower for $\mathrm{Nb}$-and Sb-doped samples than for pure $\mathrm{SnO}_{2}$. The peak at $45 \mathrm{~nm}$ is even smaller for $\mathrm{Sb}$ doped samples. The decrease in porosity around $45 \mathrm{~nm}$ may be related to the SEM observations and the change in size of the particle agglomerates.

To sum up, a multimodal distribution with broad peaks centered around $25 \mathrm{~nm}$ and $45 \mathrm{~nm}$ was observed for $\mathrm{Sb}$ and $\mathrm{Nb}$ doped $\mathrm{SnO}_{2}$.

In line with SEM observations, xerogel samples showed smaller specific surface areas than aerogel samples and much smaller porous volumes $\left(0.1 \mathrm{~cm}^{3} / \mathrm{g}\right.$ vs $\left.0.3 \mathrm{~cm}^{3} / \mathrm{g}\right)$. Accordingly, the microporous volume is also negligible, at two orders of magnitude smaller than that of aerogels. 
In the case of xerogels, the specific surface area clearly increases with the Sb content. It is noteworthy that the 10 and 15 at.\% doped xerogel samples showed surprisingly high specific surface areas of around $60 \mathrm{~m}^{2} / \mathrm{g}$, close to the aerogel one.

Xerogel pore size distribution is also significantly different. Only one peak is observed for pure $\mathrm{SnO}_{2}$, centered at around $13 \mathrm{~nm}$. This peak shifts toward smaller diameters with the increase in Sb content. It is centered at around $4 \mathrm{~nm}$ for $\mathrm{SnO}_{2}: \mathrm{Sb} 15$ at.\%. Such behavior is consistent with our SEM observations and literature that reports a decrease in particle size after doping.

So, despite negligible microporous volume and quite high specific surface area, due to pore size distributions centered on small mesopores (all $<15 \mathrm{~nm}$ ), xerogels appear less appropriate for the application.

Table 1 Nitrogen sorption measurement results $-\mathrm{SnO}_{2}$ aerogel samples (calcined for $5 \mathrm{~h}$ at $600{ }^{\circ} \mathrm{C}$ in air)

\begin{tabular}{cccccc}
\hline Sample & $\begin{array}{c}\text { Dopant-Rate } \\
(\text { at. } \%)\end{array}$ & $\begin{array}{c}\text { S BET } \\
\left(\mathrm{m}^{2} / \mathrm{g}\right)\end{array}$ & $\begin{array}{c}\text { PSD (BJH) } \\
(\mathrm{nm})\end{array}$ & $\begin{array}{c}\text { Pore Volume } \\
(\mathrm{BJH}) \\
\left(\mathrm{cm}^{3} / \mathrm{g}\right)\end{array}$ & $\begin{array}{c}\mu \text { pore volume } \\
(\mathrm{t}-\mathrm{plot}) \\
\left(\mathrm{cm}^{3} / \mathrm{g}\right)\end{array}$ \\
\hline A6S & $\mathrm{x}-\mathrm{x}$ & $15-20-40$ & 0.31 & $1.5 \times 10^{-2}$ \\
\hline A6SN050 & $\mathrm{Nb}-5$ & 76 & $20-30-45$ & 0.21 & $1.2 \times 10^{-2}$ \\
\hline A6SN100 & $\mathrm{Nb}-10$ & 87 & $20-30-45$ & 0.29 & $1.3 \times 10^{-2}$ \\
\hline A6SS050 & $\mathrm{Sb}-5$ & 56 & $20-30-45$ & 0.21 & $0.4 \times 10^{-2}$ \\
\hline A6SS100 & $\mathrm{Sb}-10$ & 85 & $20-45$ & 0.27 & $0.8 \times 10^{-2}$ \\
\hline A6SS150 & $\mathrm{Sb}-15$ & 42 & $15-25-40$ & 0.13 & $0.5 \times 10^{-2}$ \\
\hline
\end{tabular}

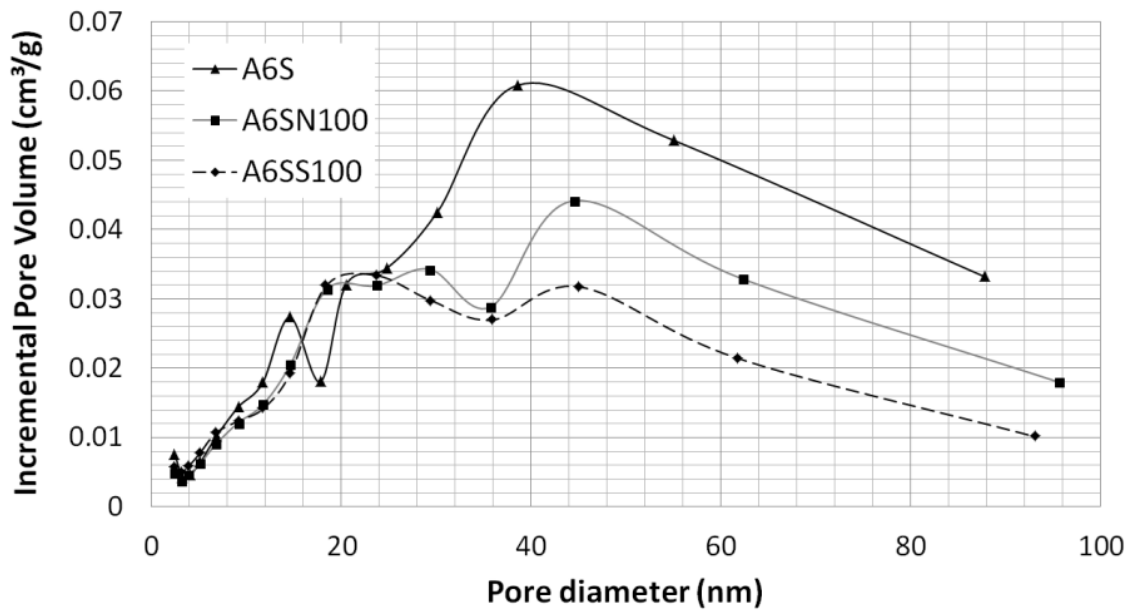

Fig. 6 Pore size distribution for pure and doped $\mathrm{SnO}_{2}$ aerogels (A6S: pure $\mathrm{SnO}_{2}, \mathrm{~A}_{6 \mathrm{SN}} 100: \mathrm{SnO}_{2}: \mathrm{Nb} 10$ at.\%, A6SS100: $\mathrm{SnO}_{2}: \mathrm{Sb} 10$ at.\%) 
Table 2 Nitrogen sorption measurement results - $\mathrm{SnO}_{2}$ xerogel samples (calcined for $5 \mathrm{~h}$ at $600{ }^{\circ} \mathrm{C}$ in air)

\begin{tabular}{cccccc}
\hline Sample & $\begin{array}{c}\text { Dopant-rate } \\
(\text { at. } \%)\end{array}$ & $\begin{array}{c}\text { S BET } \\
\left(\mathrm{m}^{2} / \mathrm{g}\right)\end{array}$ & $\begin{array}{c}\text { PSD(BJ } \\
\mathrm{H})\end{array}$ & $\begin{array}{c}\text { Pore Volume } \\
(\mathrm{nm})\end{array}$ & $\begin{array}{c}\mu \text { pore volume } \\
(\mathrm{cm})\end{array}$ \\
\hline X6S & $\mathrm{X}-\mathrm{x}$ & 21 & 13 & 0.10 & $1.6 \times 10^{-4}$ \\
\hline X6SS010 & $\mathrm{Sb}-1$ & 20 & 13 & 0.09 & $1.0 \times 10^{-4}$ \\
\hline X6SS020 & $\mathrm{Sb}-2$ & 23 & 11 & 0.09 & $1.7 \times 10^{-4}$ \\
\hline X6SS050 & $\mathrm{Sb}-5$ & 32 & 7 & 0.09 & $1.6 \times 10^{-4}$ \\
\hline X6SS100 & $\mathrm{Sb}-10$ & 57 & 6 & 0.09 & $1.6 \times 10^{-4}$ \\
\hline X6SS150 & $\mathrm{Sb}-15$ & 63 & 4 & 0.08 & $1.6 \times 10^{-4}$ \\
\hline
\end{tabular}

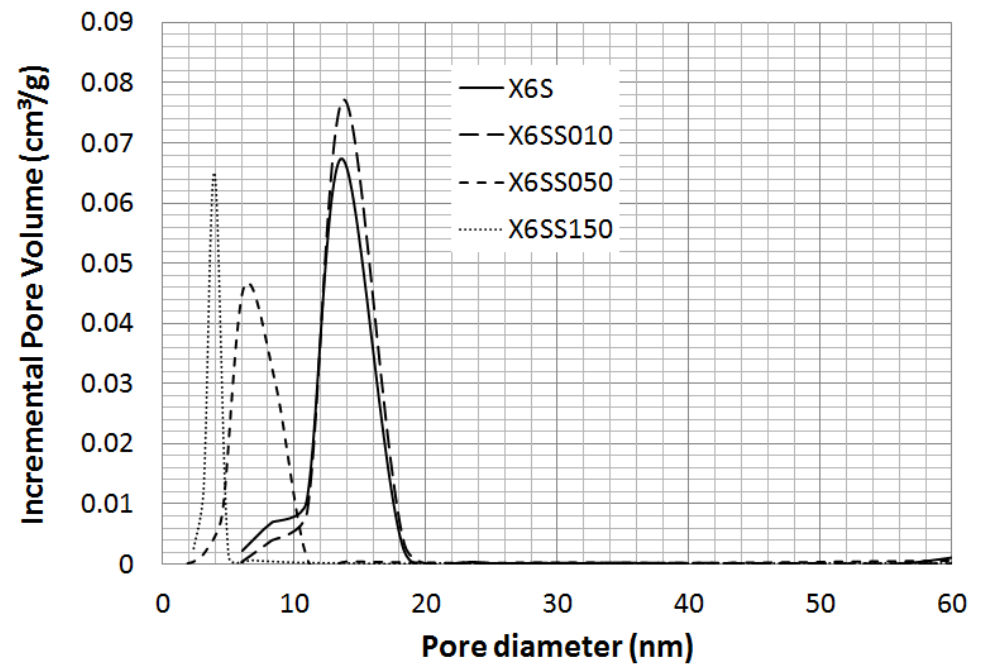

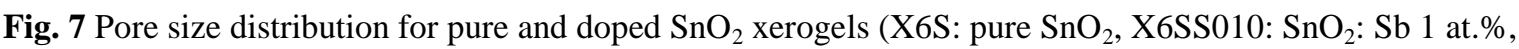
X6SS050: $\mathrm{SnO}_{2}: \mathrm{Sb} 5$ at.\%, X6SS150: $\mathrm{SnO}_{2}: \mathrm{Sb} 15$ at.\%)

\section{Chemical composition}

Chemical composition obviously impacts electronic conductivity. Although the amount of dopant precursor can be perfectly controlled during the sol-gel process, the exact concentration of dopant and its repartition in the final material has to be analyzed. The homogeneity of the sol may indeed not be optimal and some precursors could also partially precipitate during the sol-gel transition, thus modifying the real dopant amount within samples. Moreover, during calcination the thermal energy can induce some atomic diffusion of the dopant within the $\mathrm{SnO}_{2}$ matrix. 
Thus, both bulk and surface chemical compositions were measured by EDX and XPS respectively. These two methods are semi-quantitative and are used to compare different samples rather than to provide their real chemical composition.
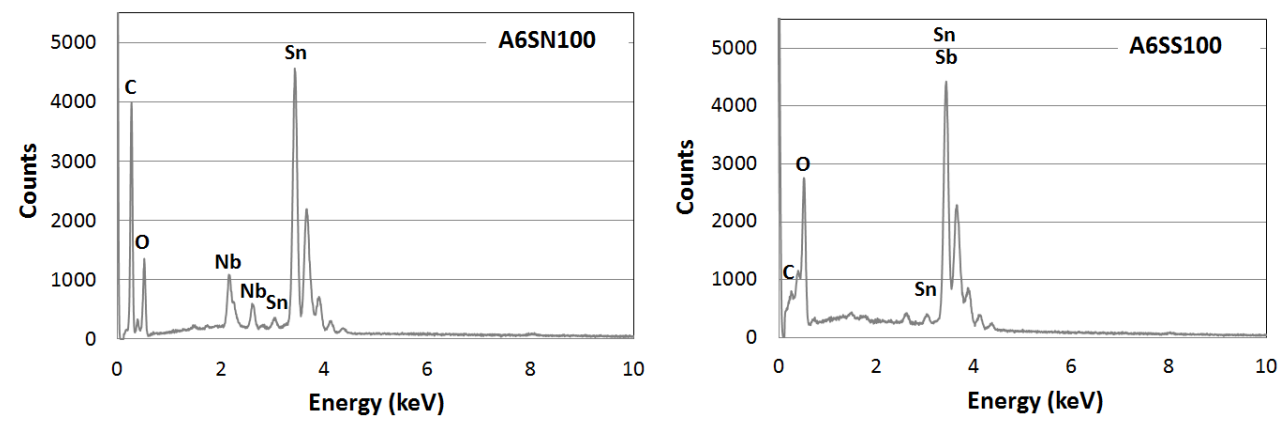

Fig. 8 EDX typical spectra obtained for $\mathrm{SnO}_{2}: \mathrm{Nb}(\mathrm{A} 6 \mathrm{SN} 100)$ and $\mathrm{SnO}_{2}: \mathrm{Sb}(\mathrm{A} 6 \mathrm{SS} 100)$ aerogels
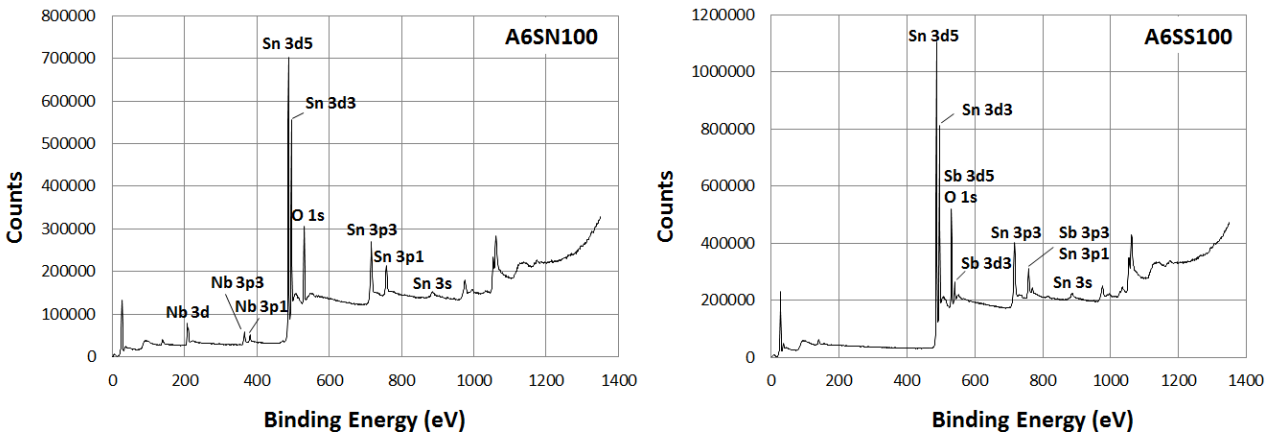

Fig. 9 XPS survey spectra obtained for $\mathrm{SnO}_{2}$ : $\mathrm{Nb}(\mathrm{A} 6 \mathrm{SN} 100), \mathrm{SnO}_{2}$ : $\mathrm{Sb}$ (A6SS100) aerogels
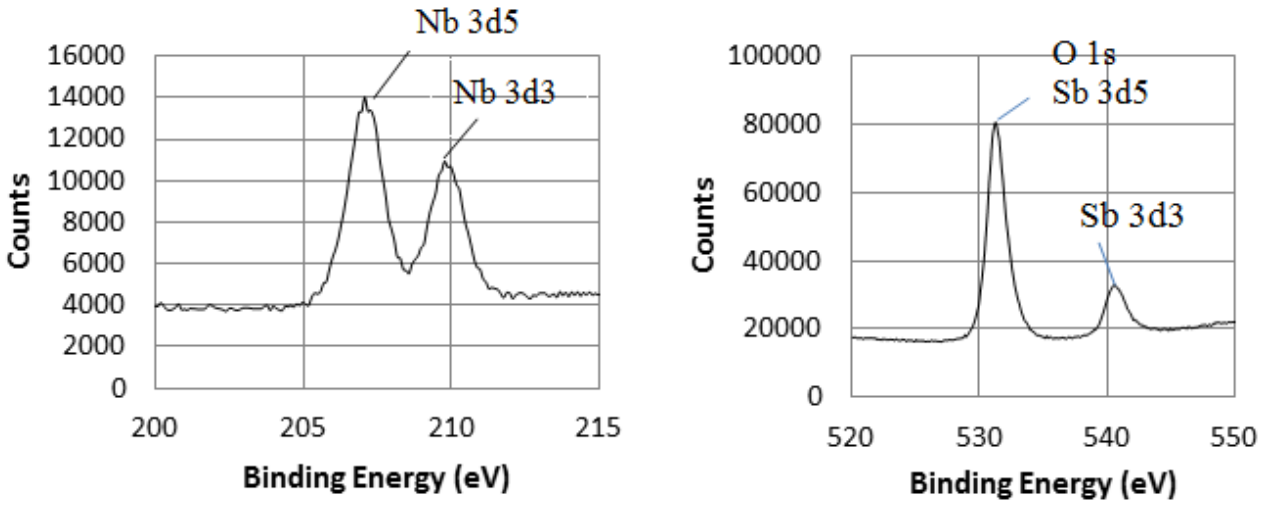

Fig. 10 XPS spectra focusing on $\mathrm{Nb} \mathrm{3d}$ (left) and $\mathrm{Sb} 3 \mathrm{~d}$ (right) 
According to the EDX measurements (Table 3), the niobium bulk concentrations correspond to the expected values for 5 and 10 at.\% doped $\mathrm{SnO}_{2}$ samples. The surface niobium concentration, measured by XPS, is however slightly higher than the bulk concentration (respectively 7 and 13 at.\% vs 5 and 10 at.\% expected for A6SN050 and A6SN100). The chemical composition does not seem to be perfectly homogenous in all $\mathrm{SnO}_{2}: \mathrm{Nb}^{2}$ samples. Such surface enrichments have already been reported by Szczuko et al. [9].

Regarding Sb-doped samples, the EDX peaks of Sn and Sb are very close due to the similar electronic structure of these two elements (Fig. 8). The doping rate calculation is thus more difficult. According to the EDX analysis, the $\mathrm{Sb}$ bulk concentration is higher than expected. This may however be a simple overestimation due to the $\mathrm{Sn}$ and $\mathrm{Sb}$ peaks overlapping. The trend is consistent for 5 and 10 at.\% doped samples whose dopant concentration was calculated respectively to 7.5 and 12 at.\%.

XPS survey spectra of $\mathrm{SnO}_{2}: \mathrm{Nb}$ and $\mathrm{SnO}_{2}$ : $\mathrm{Sb}$ aerogels are shown on Fig. 9. Similar difficulties than for EDX analysis arose to quantify $\mathrm{Sb}$ rate at the surface, since the most intense peak of $\mathrm{Sb}$ ( $\mathrm{Sb} 3 \mathrm{~d} 5$ ) stands at the same binding energy as the $\mathrm{O} 1$ s peak. Thus, we performed measurements considering a less intense $\mathrm{Sb}$ peak ( $\mathrm{Sb} 3 \mathrm{~d} 3$ ) (Fig. 10). As for EDX, the characterization accuracy of Sb-doped samples is rather poor but comparison is still possible. As shown in Table 3, the Sb rate is also higher than expected on the surface, whatever the expected amount of Sb. The surface concentrations are still slightly larger than the bulk ones. They may also have been overestimated. As already observed [44, 45], $\mathrm{Sb}$ seems also prone to segregation in our $\mathrm{SnO}_{2}$ aerogels (about $10 \%$ more $\mathrm{Sb}$ measured on surface vs volume), however in a lesser extent than $\mathrm{Nb}$ ( $30 \%$ more $\mathrm{Nb}$ measured on surface vs volume).

If such segregations reveal to be problematic in fuel cell operating conditions, we will try to mitigate them through accurate selection or modification of metal precursors. Segregation may indeed result from different hydrolysis or condensation kinetics with the precursors used. In our case, tin isopropoxide may be more reactive than niobium and antimony isopropoxide. Segregation can probably be mitigated selecting or even synthesizing precursors with similar hydrolysis/condensation kinetics. 
Table 3 Chemical composition of aerogels from EDX and XPS measurements

\begin{tabular}{cccc}
\hline Sample & $\begin{array}{c}\text { Dopant-rate } \\
\text { (at.\%) }\end{array}$ & $\begin{array}{c}\mathrm{x} /(\mathrm{x}+\mathrm{Sn})^{*} \\
\mathrm{EDX} \\
\text { (at.\%) }\end{array}$ & $\begin{array}{c}\mathrm{x} /(\mathrm{x}+\mathrm{Sn})^{*} \\
\mathrm{XPS} \\
\text { (at.\%) }\end{array}$ \\
\hline A6SN050 & $\mathrm{Nb}-5$ & 5.5 & 7 \\
\hline A6SN100 & $\mathrm{Nb}-10$ & 10 & 13 \\
\hline A6SS050 & $\mathrm{Sb}-5$ & 7.5 & 8 \\
\hline A6SS100 & $\mathrm{Sb}-10$ & 12.0 & 13.5 \\
\hline
\end{tabular}

$\mathrm{x}=\mathrm{Nb}$ or $\mathrm{Sb}$

\section{Electronic conductivity measurement}

High electronic conductivity is essential for a material to be a good catalyst support in PEMFC. As metal oxides are by definition dielectric, high conductivity can only be obtained by modifying their electronic configuration. Doping is one option, as followed in this work. It is of paramount importance to check how the dopant type and concentration influence the electronic conductivity of doped samples. In this section, the electronic conductivity was measured for different $\mathrm{Nb}$ and $\mathrm{Sb}$ concentrations and compared to that of pure $\mathrm{SnO}_{2}$ on one hand and carbon on the other hand. All materials were analyzed in the same conditions. In order to limit the impact of interface resistance between particles, measurements were first performed on xerogel sample pieces. This allowed us to study the influence of both the dopant type and its concentration. Measurement errors are quite high due to surface roughness of the samples, which was not possible to improve.

$\mathrm{Nb}^{5+}$ doping was first selected to increase the $\mathrm{SnO}_{2}$ conductivity (Table 4). Typical impedance curves obtained for $\mathrm{Nb}$-doped $\mathrm{SnO}_{2}$ exhibit a characteristic half circle arc that is representative of a semi-conductor behavior (Fig. 11). The high frequency resistance is representative of bulk resistance, and the diameter of the half circle corresponds to that of interface resistances. We used both to analyze the conductivity of our samples.

The bulk conductivity of $\mathrm{SnO}_{2}$ is considerably low $\left(5 \times 10^{-4} \mathrm{~S} / \mathrm{cm}\right)$. The interface resistance between particles is relatively high, resulting in lower global conductivity, even for doped samples.

Compared to pure $\mathrm{SnO}_{2}$, $\mathrm{Nb}$-doped samples exhibit a significant improvement in bulk electronic conductivity. $5 \times 10^{-3} \mathrm{~S} / \mathrm{cm}$ was reached for 10 at. $\%$ of $\mathrm{Nb}$, i.e. one order of magnitude higher than that of pure $\mathrm{SnO}_{2}$. $\mathrm{The}$ improvement in global conductivity is very low compared to that of bulk conductivity, here again due to 
significant interface resistances. The doping inhibits grain growth during the sol gel process, as mentioned above and in agreement with SEM observations and pore-size distribution calculations. Hence, the number of interfaces should be greater for doped materials, thus partially accounting for the limited improvement in the global conductivity.

The bulk conductivities of Nb-doped samples are still very low and far from that of Vulcan XC-72.

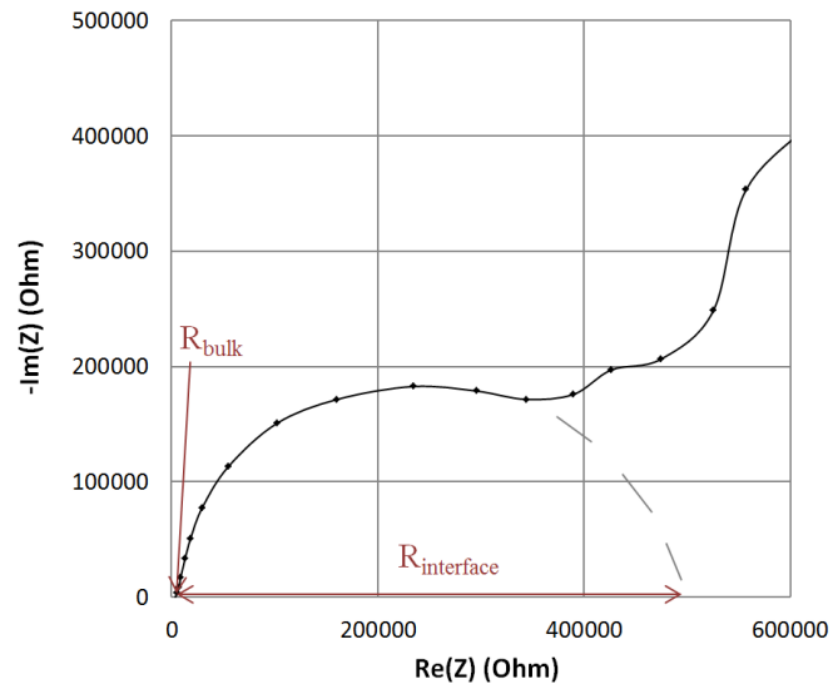

Fig. 11 Nyquist plot obtained for $\mathrm{SnO}_{2}: \mathrm{Nb} 10$ at.\% xerogel

Table $4 \mathrm{SnO}_{2}$ : $\mathrm{Nb}$ conductivities obtained from Impedance Spectroscopy measurements on xerogel samples

\begin{tabular}{lccc}
\hline Samples & $\begin{array}{c}\text { Dopant- } \\
\text { rate (at.\%) }\end{array}$ & $\begin{array}{c}\text { Bulk } \\
\text { conductivity } \\
10^{-5}(\mathrm{~S} / \mathrm{cm})\end{array}$ & $\begin{array}{c}\text { Global } \\
\text { conductivity } \\
10^{-5}(\mathrm{~S} / \mathrm{cm})\end{array}$ \\
\hline X6S & - & $53 \pm 2$ & $1.9 \pm 1.3$ \\
\hline X6SN020 & $\mathrm{Nb}-2$ & $63 \pm 11$ & $1.0 \pm 0.4$ \\
\hline X6SN100 & $\mathrm{Nb}-10$ & $490 \pm 360$ & $4.5 \pm 3.6$ \\
\hline
\end{tabular}

In agreement with other studies [9, 31, 33, 36, 46, 47], an impressive improvement in conductivity was observed for Sb-doped $\mathrm{SnO}_{2}$ (Table 5). X6SS100 (10 at.\% Sb-doped $\mathrm{SnO}_{2}$ xerogel) shows indeed the typical behavior of a conducting material (Fig. 12). No impact of grain boundaries can be observed on the Nyquist plot. In agreement with Bruneaux et al. [48], this may result from a higher charge carriers density than in the case of $\mathrm{Nb}$ doping. Whatever the Sb rate between 2 at.\% and 15 at.\%, conductivities were improved by at least 4 orders of magnitude compared to pure $\mathrm{SnO}_{2}$. The electronic conductivity reached a maximum of about $1 \mathrm{~S} / \mathrm{cm}$ for 5 at. $\%$ $\mathrm{Sb}$, a value very close to that reported for Vulcan XC-72 (4 S/cm). 


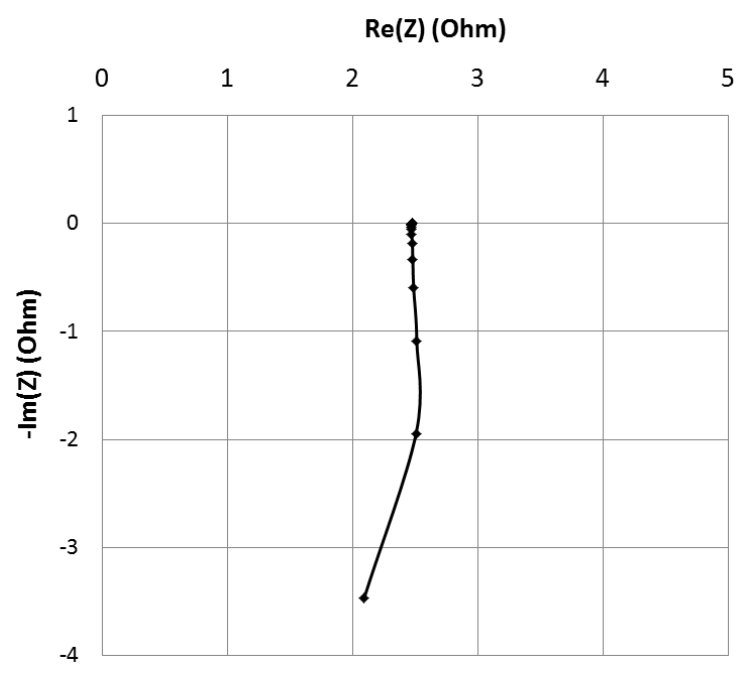

Fig. 12 Nyquist plot obtained for $\mathrm{SnO}_{2}: \mathrm{Sb} 10$ at.\% xerogel

Table $5 \mathrm{SnO}_{2}$ : $\mathrm{Sb}$ conductivity obtained from Impedance Spectroscopy measurements on xerogel samples

\begin{tabular}{ccc}
\hline Samples & $\begin{array}{c}\text { Dopant-rate } \\
\text { (at.\%) }\end{array}$ & $\begin{array}{c}\text { Conductivity } \\
\text { (S/cm) }\end{array}$ \\
\hline $\mathrm{X} 6 \mathrm{~S}$ & - & $1.9 \times 10^{-5} \pm 1.3 \times 10^{-5}$ \\
\hline $\mathrm{X} 6 \mathrm{SS} 020$ & $\mathrm{Sb}-2$ & $0.41 \pm 0.16$ \\
\hline $\mathrm{X} 6 \mathrm{SS} 050$ & $\mathrm{Sb}-5$ & $0.97 \pm 0.14$ \\
\hline $\mathrm{X} 6 \mathrm{SS} 100$ & $\mathrm{Sb}-10$ & $0.81 \pm 0.4$ \\
\hline $\mathrm{X} 6 \mathrm{SS} 150$ & $\mathrm{Sb}-15$ & $0.71 \pm 0.39$ \\
\hline
\end{tabular}

Based on this first series of results, $\mathrm{Sb}$ was selected as the favored dopant to determine the conductivity of doped $\mathrm{SnO}_{2}$ aerogels.

Aerogel materials are not monolithic enough after calcination to allow impedance spectroscopy measurements and it was difficult to prepare pellets. We thus produced a homemade cell to measure the resistance of aerogel materials, pressed between two electrodes inserted into a Teflon cylinder. For comparison purposes, we also measured the resistance of xerogels in the same conditions.

The evolution of conductivity with the pressure applied on the sample through the electrodes is shown in Fig. 13 for xerogels and Fig. 14 for aerogels. 
As expected, the conductivity increases with the pressure applied. No significant difference was observed following a change in the current $(+105 \mathrm{~mA},-105 \mathrm{~mA}$ or $400 \mathrm{~mA})$. In most cases, a plateau is reached from 6.5 $\times 10^{2} \mathrm{~kg} / \mathrm{cm}^{2}$ of applied pressure.

Fig. 15 represents the evolutions of conductivity for aerogels and xerogels as a function of the antimony doping rate and for the two methods used in this study (1: EIS, 2: direct resistance measurement).

First, conductivity values obtained with the homemade cell $\left(13 \times 10^{2} \mathrm{~kg} / \mathrm{cm}^{2}\right.$ pressure, data referenced (2) on Fig. 15) are 4 times higher than those obtained with impedance spectroscopy (data referenced (1) in Fig. 15). This is probably due to better contact between particles resulting from the relatively high pressure applied.

Then, the conductivity of xerogels is roughly between one and two orders of magnitude higher than that of aerogels.

Finally, whatever the measurement technique, the conductivity reaches a maximum for 5 at.\% Sb doping rate in the case of xerogels and between 5 and 10 at. $\%$ in the case of aerogels.
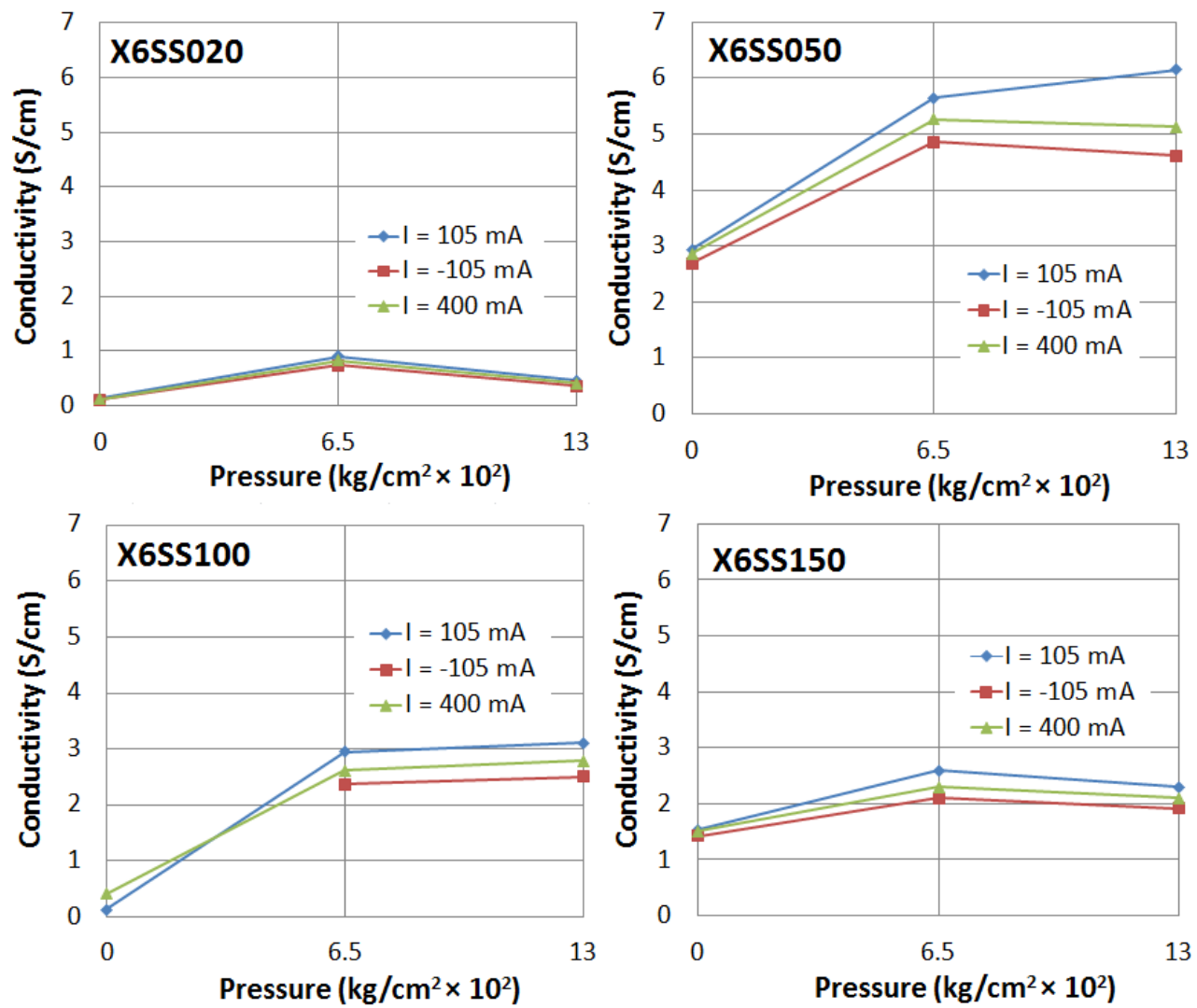

Fig. 13 Evolution of electronic conductivity with pressure applied on $\mathrm{SnO}_{2}$ : $\mathrm{Sb}$ xerogels - (2 at.\%-X6SS020, 5 at. $\%$-X6SS050, 10 at.\%-X6SS100 and 15 at.\%-X6SS150) 


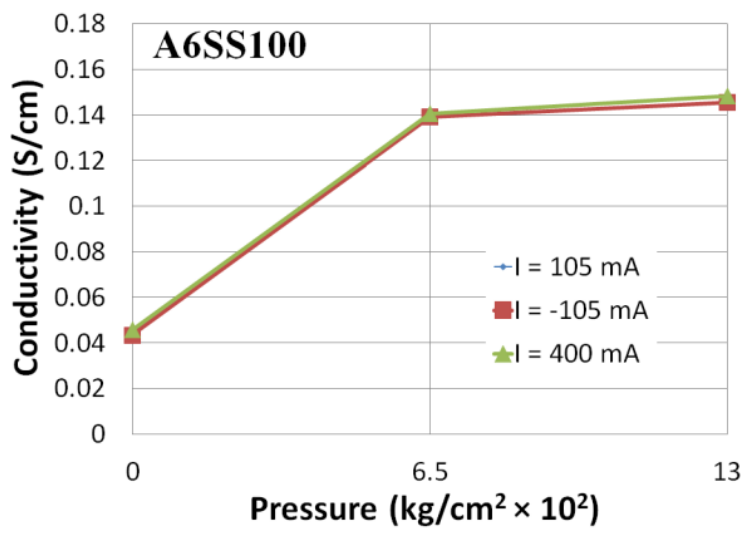

Fig. 14 Evolution of electronic conductivity with pressure applied on $\mathrm{SnO}_{2}$ : $\mathrm{Sb}$ samples - (5 at.\%-A6SS050 and 10 at. $\%-\mathrm{A} 6 \mathrm{SS} 100)$

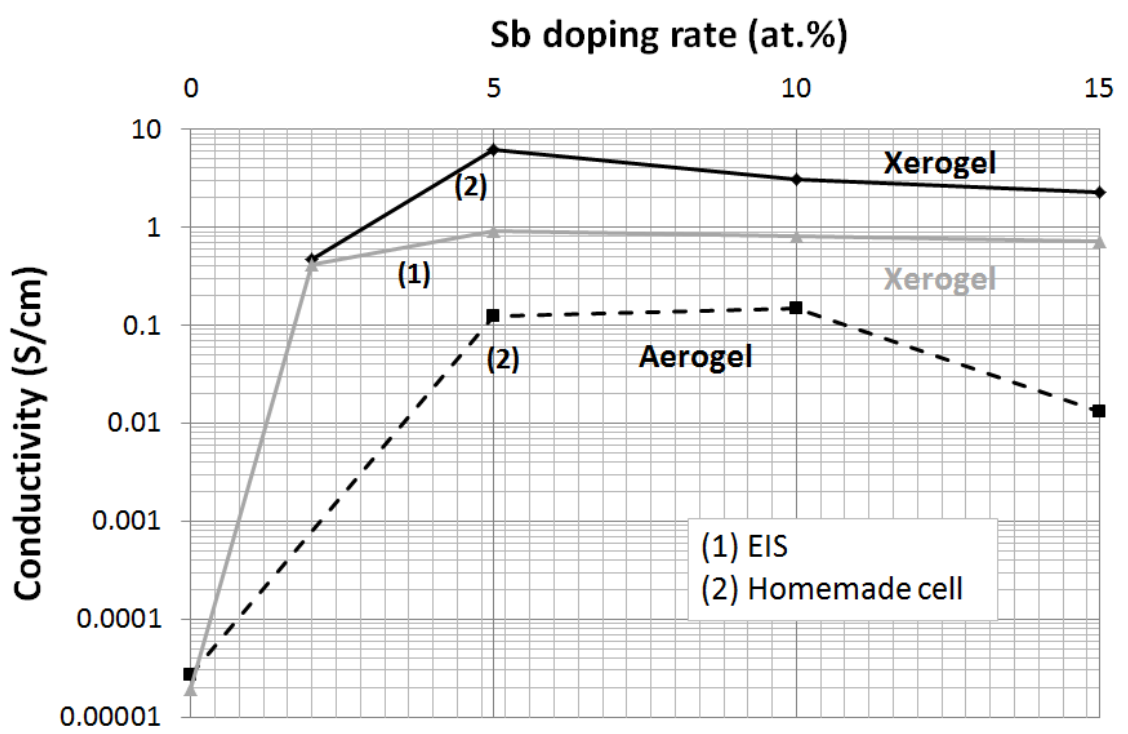

Fig. 15 Xerogel and aerogel conductivity for different Sb-doping rates ( (2) : P = $13 \times 10^{2} \mathrm{~kg} / \mathrm{cm}^{2}$ )

\section{Discussion}

The purpose of this study was to synthetize a new corrosion resistant catalyst support for PEMFC. Both the morphology and the electronic conductivity are of major importance considering the foreseen application. In a first part, the unique material morphology will be highlighted in comparison with those reported in the literature. In a second part the electronic conductivity and its evolution with materials composition will be discussed. 
Morphology

Considering the morphology, we have already stated that both the presence of meso and macropores are beneficial to fluid management within electrodes [43]. Moreover, since the optimum Pt particle size was reported to be between 3 and $4 \mathrm{~nm}$ in diameter, microporosity should be avoided and may become clogged after the deposition of platinum nanoparticles. Mesopores on the contrary allow good platinum nanoparticle dispersion while avoiding pore obstruction, still leaving room for high gas flow rates. Macropores are also beneficial to efficiently manage water coming from humidified gases and that produced during ORR.

Regarding such considerations, all $\mathrm{SnO}_{2}$ aerogels show a very interesting morphology. Combining specific surface area close to $90 \mathrm{~m}^{2} / \mathrm{g}$, adequate pore size distribution revealing medium and large mesopores (25 and 45 $\mathrm{nm})$ and negligible microporous volume, they are particularly well adapted to the foreseen application.

Little research has been reported on such an interesting morphology, mixing a high specific surface area with wide pore size distribution. Our materials show higher values for $\mathrm{SnO}_{2}$ than most of those reported in literature $[26,27,33]$. Usually, high specific surface area is developed at the expense of wide pore size distribution and vice versa. Indeed, high specific surface area nanostructured $\mathrm{Sb}$-doped $\mathrm{SnO}_{2}$ materials have already been synthesized. Lee et al. [49] achieved $100 \mathrm{~m}^{2} / \mathrm{g}$ from chloride precipitation in basic conditions. Sol-gel route using template, dodecylamine $[31,50]$ or tetradecylamine [34] also provide high specific surface areas with respectively $216 \mathrm{~m}^{2} / \mathrm{g}$ and $263 \mathrm{~m}^{2} / \mathrm{g}$. However, these materials show a narrow pore size distribution centered on few nm only.

Although the specific surface areas developed by our materials are still lower than that of Vulcan XC-72 (254 $\mathrm{m}^{2} / \mathrm{g}$ ), a general carbon black reference, the difference in bulk density is in favor of $\mathrm{SnO}_{2}$. We may actually expect a similar developed surface area for the same volume. Since our aerogels crack after calcination, it was unfortunately not possible to measure their density. This advantage will be checked after electrochemical characterizations.

Thus, from a morphology point of view, the materials developed in this study are promising candidates for PEMFC catalyst support. 


\section{Electronic conductivity}

High enough electronic conductivities where achieved only after doping with Sb. Doping with $\mathrm{Nb}$ allowed improving electronic conductivity by a factor of only 2 compared to undoped $\mathrm{SnO}_{2}$, what remains too low for the foreseen application. Doping may actualy have been less efficient with $\mathrm{Nb}$ than with $\mathrm{Sb}$. On one hand, the degree of segregation seems to be larger for $\mathrm{Nb}$ (see table 3 ) and on the other hand the repartition of the dopant in the $\mathrm{SnO}_{2}$ matrix may be less homogeneous, resulting in possible local $\mathrm{Nb}$ rich regions. Moreover, we cannot exclude the possibility of amorphous $\mathrm{Nb}$ oxide regions which would concentrate $\mathrm{Nb}$ at the expense of $\mathrm{SnO}_{2}$. Finally the association of defects due to the introduction of dopant in $\mathrm{SnO}_{2}$ may be less prone to increase the electronic conductivity in the case of $\mathrm{Nb}$ than in the case of $\mathrm{Sb}$.

Most of the conductivities reported in literature $[9,33,46,47]$ were measured using different levels of pressure applied on samples. Since conductivity obviously depends on powder density (the higher the density, the higher the conductivity), it is quite difficult to compare reported conductivity values from one study to another. However, the values obtained in our study for $\mathrm{Sb}$-doped $\mathrm{SnO}_{2}$ xerogels are among the highest reported ones.

The observed evolution of electronic conductivity with the antimony dopant rate and the presence of a maximum have already been reported $[9,28,31,33,46,47]$. This may be related to the oxidation state of the dopant.

$\mathrm{SnO}_{2}$ is known to be an oxygen-deficient non-stoichiometric oxide $\left(\mathrm{SnO}_{2-\delta}\right)$ [51]. Its intrinsic electronic conductivity results from the presence of oxygen vacancies $\left(\mathrm{V}_{\mathrm{O}} \cdot{ }^{*}\right)$ which are compensated with electrons. Hence, the non-stochiometry of $\mathrm{SnO}_{2}$ gives rise to an n-type conductivity according to the equilibrium (1):

$$
2 \mathrm{O}_{\mathrm{O}}^{\mathrm{x}} \leftrightarrows \mathrm{O}_{2}(\mathrm{~g})+4 \mathrm{e}^{\prime}+2 \mathrm{~V}_{\mathrm{O}}^{\circ}
$$

When $\mathrm{SnO}_{2}$ is doped with $\mathrm{Sb}$, a possible competition between the two antimony oxidation states has been suggested [52-55]. It has been shown that when $\mathrm{Sb}^{3+}$ is incorporated into $\mathrm{SnO}_{2}$, it is oxidized during calcination in air [56]. This oxidation to $\mathrm{Sb}^{5+}$ is favored in the presence of $\mathrm{SnO}_{2}$, which acts as a catalyst and a stabilizer of the $\mathrm{Sb}^{5+}$ state. This results in an increased $\mathrm{Sb}^{5+} / \mathrm{Sb}^{3+}$ ratio. The lower the $\mathrm{Sb}$ content, the higher the $\mathrm{Sb}^{5+} / \mathrm{Sb}^{3+}$ ratio. 
For low doping rates, the antimony is agreed to be stabilized in a +5 state after calcination. According to geometrical considerations, the substitution, in the $\mathrm{SnO}_{2}$ lattice, of $\mathrm{Sn}^{4+}$ ions with $\mathrm{Sb}^{5+}$ ions is allowed thanks to compatible ionic radius. Such a substitution leads to the generation of positively charged point defects $\mathrm{Sb}_{\mathrm{Sn}}{ }^{\circ}$ which can be compensated by creating tin vacancies what can be represented with the equation (2):

$$
2 \mathrm{Sb}_{2} \mathrm{O}_{5} \stackrel{\text { SnO2 }}{\longrightarrow} 4 \mathrm{Sb}_{S n}^{\circ}+10 O_{O}^{x}+V_{S n}^{4 \prime}
$$

These tin vacancies may then react with native oxygen vacancies, decreasing their concentration (at constant temperature and $\mathrm{O}_{2}$ partial pressure). Such a decrease in oxygen vacancy concentration impacts the equilibrium (1) (right shift) resulting in a higher concentration of electrons in the lattice. Hence, the introduction of $\mathrm{Sb}^{5+}$ results in increased conductivity, as observed up to 5 at.\% with xerogel samples.

For higher doping rates, $\mathrm{Sb}^{5+}$ is no longer favored and $\mathrm{Sb}^{3+}$ is stabilized. It substitutes $\mathrm{Sn}^{4+}$ as possibly represented with the equilibrium (3):

$$
\mathrm{Sb}_{2} \mathrm{O}_{3} \stackrel{\mathrm{SnO2}}{\longrightarrow} 2 \mathrm{Sb}_{S n}^{\prime}+3 \mathrm{O}_{O}^{x}+V_{O}^{\circ \circ}
$$

The creation of oxygen vacancies according to equilibrium (3) now impacts equilibrium (1) in the opposite direction, making the electron concentration decrease. Consequently, the electronic conductivity decreases, as experimentally observed from 5 at.\% on xerogel samples.

This hypothesis could partially explain the observed conductivity trend. It is however incomplete because it does not account for different parameters, such as the charge carrier mobility, the change in morphology between samples with different doping rates, and the effect of $\mathrm{Sn}^{4+} / \mathrm{Sn}^{2+}$ transition. It has also been reported that $\mathrm{Sb}^{3+}$ cannot fit in $\mathrm{Sn}^{4+}$ octahedral coordination as good as $\mathrm{Sb}^{5+}$, which induces charge defects [48].

All conductivity values obtained here are not really representative of real catalytic layer conductivities. They are useful to compare samples and select the proper dopant and its concentration. The conductivity of aerogels measured here is notably lower than that of xerogels and carbon. It is however noteworthy that the doped $\mathrm{SnO}_{2}$ materials developed in this study are intended to be used as platinum support for fuel cell application. $\mathrm{Pt}$ nanoparticles deposited at the surface of $\mathrm{SnO}_{2}$ may then lower the depletion layer resulting from adsorbed oxygen species $\left(\mathrm{O}_{2}^{-}, \mathrm{O}^{-}\right.$or $\left.\mathrm{O}^{2-}\right)$ limiting the electronic conductivity [57]. Thus as already reported $[35,58]$ we might expect an improvement in the conductivity after Pt deposition. This will be checked in a further study. 


\section{Conclusion}

Antimony and niobium-doped tin dioxide xerogels and aerogels were synthesized by a sol-gel route starting with metal alkoxide precursors. After calcination at $600{ }^{\circ} \mathrm{C}$ in air, only the rutile crystal phase of $\mathrm{SnO}_{2}$ was detected by XRD for all samples, whether pristine or doped.

Due to their unique morphology, our $\mathrm{Nb}$ - and $\mathrm{Sb}$-doped $\mathrm{SnO}_{2}$ aerogels appear to be very promising catalyst supports for PEMFC cathode.

Aerogel samples show an interconnected particle network, particularly pronounced for Sb-doped samples, with bimodal mesoporous pore size distributions.

Doping $\mathrm{SnO}_{2}$ induces airier morphologies and leads to quite high specific surface areas: $85 \mathrm{~m}^{2} / \mathrm{g}$ for both $\mathrm{SnO}_{2}$ : $\mathrm{Nb}\left(10\right.$ at.\%) and $\mathrm{SnO}_{2}: \mathrm{Sb}(10$ at.\%).

As expected from the drying route, xerogels are denser and present only very small pore diameters $(<20 \mathrm{~nm})$. Highly doped xerogel samples, however, show surprisingly high specific surface areas (60 $\mathrm{m}^{2} / \mathrm{g}$ for $10 \mathrm{at} . \% \mathrm{Sb}$ ).

All Sb-doped samples exhibited an impressive improvement in electronic conductivity compared to pure $\mathrm{SnO}_{2}$. An increase of at least a 4 orders of magnitude has been recorded after doping $\mathrm{SnO}_{2}$ xerogels with $\mathrm{Sb}$, to reach electronic conductivities of about $1 \mathrm{~S} / \mathrm{cm}\left(\mathrm{SnO}_{2}: \mathrm{Sb}(5\right.$ at.\%)), one order of magnitude less for aerogels. This value is even very close to that of carbon Vulcan XC-72 (4 S/cm).

Only poor conductivities were achieved for $\mathrm{Nb}$-doped samples $\left(4.5 \times 10^{-5} \mathrm{~S} / \mathrm{cm}\right.$ for 10 at. $\%$ of $\mathrm{Nb}$ versus $2 \times 10^{-5}$ $\mathrm{S} / \mathrm{cm}$ for pure $\mathrm{SnO}_{2}$ ).

To conclude, with an adequate morphology (high specific surface area, bimodal pore size distribution centered on 25 and $45 \mathrm{~nm}$, negligible microporous volume) and thanks to a high bulk electronic conductivity close to that of Vulcan XC-72, Sb-doped $\mathrm{SnO}_{2}$ aerogel samples are very promising candidates as catalyst supports for PEMFC cathodes.

Future work will center on Pt deposition and catalytic performance assessment (activity and durability).

\section{AUTHOR INFORMATION}

Corresponding Author: christian.beauger@ mines-paristech.fr

Author Contributions: the manuscript was written through contributions of all authors. 


\section{ACKNOWLEDGMENTS}

The authors wish to thank Pierre Ilbizian for supercritical drying, Frédéric Georgi for XPS analysis, Suzanne Jacomet for SEM/EDX analysis as well as Frédéric Fabry and Matthieu Houllé for their help in manufacturing the homemade conductivity measurement cell. This work was funded by the European Union's Seventh Framework Program for the Fuel Cells and Hydrogen Joint Technology Initiative under grant agreement n325239 (FCH-JU project Nano-CAT) and the French National Research Agency PROGELEC programme, (ANR-12-PRGE-007 project SURICAT). It was supported by Capenergies and Tenerrdis.

The final publication is available at Springer via http://dx.doi.org/[10.1007/s10853-016-9833-7]

\section{References}

1. Rabis A, Rodriguez P, Schmidt TJ (2012) Electrocatalysis for Polymer Electrolyte Fuel Cells: Recent Achievements and Future Challenges. Acs Catal 2(5):864-890.

2. Costamagna P, Srinivasan S (2001) Quantum jumps in the PEMFC science and technology from the 1960s to the year 2000 Part I. Fundamental scientific aspects. J Power Sources 102 (1-2):242-252.

3. Haile SM (2003) Fuel cell materials and components. Acta Materialia 51 (19):5981-6000.

4. Antolini E (2009) Carbon supports for low-temperature fuel cell catalysts. Appl Catal B-Environ. 88 (12):1-24.

5. Maass S, Finsterwalder F, Frank G, Hartmann R, Merten C (2008) Carbon support oxidation in PEM fuel cell cathodes. J Power Sources 176 (2):444-451.

6. Yasuda K, Taniguchi A, Akita T, Ioroi T, Siroma Z (2006) Platinum dissolution and deposition in the polymer electrolyte membrane of a PEM fuel cell as studied by potential cycling. Phys Chem Chem Phys 8 (6):746-752.

7. Sasaki K, Hayashi S, Kanda K, Takabatake Y, Tsukatsune T, Higashi T, Takasaki F, Noda Z, Hayashi A (2012) Alternative Electrocatalyst Support Materials for Polymer Electrolyte Fuel Cells. The Electrochem Soc Meeting Abstracts 1684.

8. Gokulakrishnan V, Parthiban S, Jeganathan K, Ramamurthi K (2011) Investigations on the structural, optical and electrical properties of Nb-doped SnO2 thin films. J Mat Sci 46 (16):5553-5558.

9. Szczuko D, Werner J, Oswald S, Behr G, Wetzig K (2001) XPS Investigations of Surface Segregation of Doping Elements in SnO2. Appl Surf Sci 179 (1-4):301-306.

10. Bressand JGE, Royer B (2009) Electrochromic device with controlled infrared reflection, european patent $2307926 \mathrm{~B} 1$.

11. Megahed S, Ebner W (1995) Lithium-ion Battery for Electronic Applications. J Power Sources 54 (1):155-162.

12. Courtney IA, Dunlap RA, Dahn JR (1999) In-situ Sn-119 Mossbauer effect studies of the reaction of lithium with $\mathrm{SnO}$ and $\mathrm{SnO}: 0.25$ B2O3 : 0.25 P2O5 glass. Electrochim Acta 45 (1-2):51-58.

13. Fuller MJ, Warwick ME (1972) The Catalytic Oxidation of Carbon Monoxide on Tin(IV) Oxide. J Catal 29:441-450.

14. Matsui T, Fujiwara K, Okanishi T, Kikuchi R, Takeguchi T, Eguchi K (2006) Electrochemical oxidation of CO over tin oxide supported platinum catalysts. J Power Sources 155 (2):152-156.

15. Herniman HJ, Pyke DR, Reid R (1979) An Investigation of the Relationship between the Bulk and Surface Composition of Tin and Antimony Mixed Oxide Catalysts and the Oxidative Dehydrogenation of I-Butene to Butadiene. J Catal 58:8-73.

16. Viricelle JP, Valleron A, Pijolat C, Breuil P, Ott S (2012) Gas Sensors Based on Tin Dioxide for Exhaust Gas Application, modeling of response for pure gases and for mixtures. 26th European Conference on Solid-State Transducers, Eurosensor 47:655-658. 
17. Shukla S, Patil S, Kuiry SC, Rahman Z, Du T, Ludwig L, Parish C, Seal S (2003) Synthesis and characterization of sol-gel derived nanocrystalline tin oxide thin film as hydrogen sensor. Sensors and Actuators B-Chem 96 (1-2):343-353.

18. Barsan N, Koziej D, Weimar U (2007) Metal oxide-based gas sensor research: How to? Sensors and Actuators B-Chemical 121 (1):18-35.

19. Masao A, Noda S, Takasaki F, Ito K, Sasaki K (2009) Carbon-Free Pt Electrocatalysts Supported on $\mathrm{SnO} 2$ for Polymer Electrolyte Fuel Cells. Electrochem Solid State Lett 12 (9):B119-B122.

20. Takabatake Y, Noda Z, Lyth SM, Hayashi A, Sasaki K (2014) Cycle durability of metal oxide supports for PEFC electrocatalysts. Int J Hydrog Energy 39 (10):5074-5082.

21. Zhang P, Huang SY, Popov BN (2010) Mesoporous Tin Oxide as an Oxidation-Resistant Catalyst Support for Proton Exchange Membrane Fuel Cells. J Electrochem Soc 157 (8):B1163-B1172.

22. Andersen SM, Norgaard CF, Larsen MJ, Skou E (2015) Tin Dioxide as an Effective Antioxidant for Proton Exchange Membrane Fuel Cells. J Power Sources 273:158-161.

23. Matsui T, Kanishi T, Fujiwara K, Tsutsui K, Kikuchi R, Takeguchi T, Eguchi K (2006) Effect of reduction-oxidation treatment on the catalytic activity over tin oxide supported platinum catalysts. Sci Technol Adv Mater 7 (6):524-530.

24. Okanishi T, Matsui T, Takeguchi T, Kikuchi R, Eguchi K (2006) Chemical interaction between Pt and $\mathrm{SnO} 2$ and influence on adsorptive properties of carbon monoxide. Appl Catal a-General 298:181-187.

25. Arenz M, Stamenkovic V, Blizanac BB, Mayrhofer KJJ, Markovic NM, Ross PN (2005) Carbonsupported Pt-Sn electrocatalysts for the anodic oxidation of $\mathrm{H}(2), \mathrm{CO}$, and $\mathrm{H}(2) / \mathrm{CO}$ mixtures. Part II: The structure-activity relationship. J Catal 232 (2):402-410.

26. Takasaki F, Matsuie S, Takabatake Y, Noda Z, Hayashi A, Shiratori Y, Ito K, Sasaki K (2011) CarbonFree Pt Electrocatalysts Supported on $\mathrm{SnO} 2$ for Polymer Electrolyte Fuel Cells: Electrocatalytic Activity and Durability. J Electrochem Soc 158 (10):B1270-B1275.

27. Kakinuma K, Chino Y, Senoo Y, Uchida M, Kamino T, Uchida H, Deki S, Watanabe M (2013) Characterization of Pt catalysts on $\mathrm{Nb}$-doped and Sb-doped $\mathrm{SnO} 2$-delta support materials with aggregated structure by rotating disk electrode and fuel cell measurements. Electrochim Acta 110:316324.

28. Cavaliere S, Subianto S, Savych I, Tillard M, Jones DJ, Roziere J (2013) Dopant-Driven Nanostructured Loose-Tube SnO2 Architectures: Alternative Electrocatalyst Supports for Proton Exchange Membrane Fuel Cells. J Phys Chem C 117 (36):18298-18307.

29. Shahgaldi S, Hamelin J (2015) The effect of low platinum loading on the efficiency of PEMFC's electrocatalysts supported on $\mathrm{TiO} 2-\mathrm{Nb}$, and $\mathrm{SnO} 2-\mathrm{Nb}$ : An experimental comparison between active and stable conditions. Energy Convers Manage 103:681-690.

30. Kakinuma K, Uchida M, Kamino T, Uchida H, Watanabe M (2011) Synthesis and electrochemical characterization of Pt catalyst supported on $\mathrm{Sn} 0.96 \mathrm{Sb} 0.04 \mathrm{O} 2$-delta with a network structure.

Electrochim Acta 56 (7):2881-2887.

31. Gurrola MP, Guerra-Balcazar M, Alvarez-Contreras L, Nava R, Ledesma-Garcia J, Arriaga LG (2013) High surface electrochemical support based on Sb-doped SnO2. J Power Sources 243, 826-830.

32. You DJ, Kwon K, Pak C, Chang H (2009) Platinum-antimony tin oxide nanoparticle as cathode catalyst for direct methanol fuel cell. Catal Today 146 (1-2):15-19.

33. Yin M, Xu JY, Li QF, Jensen JO, Huang YJ, Cleemann LN, Bjerrum NJ, Xing W (2014) Highly active and stable Pt electrocatalysts promoted by antimony-doped $\mathrm{SnO} 2$ supports for oxygen reduction reactions. Appl Catal B-Environ 144:112-120.

34. Oh HS, Nong HN, Strasser P (2015) Preparation of Mesoporous Sb-, F-, and In-Doped SnO2 Bulk Powder with High Surface Area for Use as Catalyst Supports in Electrolytic Cells. Adv Func Mater 25(7):1074-1081.

35. Senoo Y, Taniguchi K, Kakinuma K, Uchida M, Uchida H, Deki S, Watanabe M (2015) Cathodic performance and high potential durability of Ta-SnO2-delta-supported Pt catalysts for PEFC cathodes. Electrochem Commun 51:37-40.

36. Avila-Vazquez V, Galvan-Valencia M, Ledesma-Garcia J, Arriaga LG, Collins-Martinez VH, GuzmanMartinez C, Escalante-Garcia IL, Duron-Torres SM (2015) Electrochemical performance of a Sb-doped $\mathrm{SnO} 2$ support synthesized by coprecipitation for oxygen reactions. J of Appl Electrochemi 45(11):11751185.

37. Leite ER, Weber IT, Longo E, Varela JA (2000) A new method to control particle size and particle size distribution of $\mathrm{SnO} 2$ nanoparticles for gas sensor applications. Adv Mater 12 (13):965-+.

38. Tauster S. J, Fung SC (1978) Strong Metal-Support Interactions - Occurrence among Binary Oxides of Groups IIA-VB. J Catal 55 (1):29-35.

39. Kamiuchi N, Matsui T, Kikuchi R, Eguchi K (2007) Nanoscopic observation of strong chemical interaction between Pt and tin oxide. J Phys Chem C 111 (44):16470-16476. 
40. Spencer MS (1985) Models of Strong Metal Support Interaction (SMSI) in Pt on TiO2 Catalysts. J Catal 93 (2):216-223.

41. Daio T, Staykov A, Guo LM, Liu JF, Tanaka M, Lyth SM, Sasaki K (2015) Lattice Strain Mapping of Platinum Nanoparticles on Carbon and SnO2 Supports. Sci Rep 5:13126.

42. Ouattara-Brigaudet M, Beauger C, Berthon-Fabry S, Achard P (2011) Carbon Aerogels as Catalyst Supports and First Insights on Their Durability in Proton Exchange Membrane Fuel Cells. Fuel Cells 11 (6):726-734.

43. Ouattara-Brigaudet M, Berthon-Fabry S, Beauger C, Chatenet M, Job N, Sennour M, Achard P (2012) Influence of the carbon texture of platinum/carbon aerogel electrocatalysts on their behavior in a proton exchange membrane fuel cell cathode. Int J Hydrog Energy 37 (12):9742-9757.

44. Fabbri E, Rabis A, Kotz R, Schmidt TJ (2014) Pt nanoparticles supported on Sb-doped SnO2 porous structures: developments and issues. Phys Chem Chem Phys 16 (27):13672-13681.

45. Rabis A, Kramer D, Fabbri E, Worsdale M, Kotz R, Schmidt TJ (2014) Catalyzed SnO2 Thin Films: Theoretical and Experimental Insights into Fabrication and Electrocatalytic Properties. J Phys Chem C 118 (21):11292-11302.

46. Muller V, Rasp M, Stefanic G, Ba JH, Gunther S, Rathousky J, Niederberger M, Fattakhova-Rohlfing D (2009) Highly Conducting Nanosized Monodispersed Antimony-Doped Tin Oxide Particles Synthesized via Nonaqueous Sol-Gel Procedure. Chem of Mater 21 (21):5229-5236.

47. Mulla IS, Soni HS, Rao VJ, Sinha APB (1986) Deposition of Improved Optically Selective Conductive Tin Oxide-Films by Spray Pyrolysis. J Mater Sci 21 (4):1280-1288.

48. Bruneaux J, Cachet H, Froment M, Messad A (1994) Structural, electrical and interfacial properties of sprayed SnO2 films. Electrochim Acta 39 (8-9):1251-1257.

49. Lee KS, Park IS, Cho YH, Jung DS, Jung N, Park HY, Sung YE (2008) Electrocatalytic activity and stability of Pt supported on Sb-doped SnO2 nanoparticles for direct alcohol fuel cells. J Catal 258 (1):143-152.

50. Gurrola MP, Gutierrez J, Rivas S, Guerra-Balcazar M, Ledesma-Garcia J, Arriaga LG (2014) Evaluation of the corrosion of Sb-doped $\mathrm{SnO} 2$ supports for electrolysis systems. Int J Hydrog Energy 39 (29):16763-16770.

51. Godinho KG, Walsh A, Watson GW (2009) Energetic and Electronic Structure Analysis of Intrinsic Defects in SnO2. J Phys Chem C 113 (1):439-448.

52. Terrier C, Chatelon JP, Berjoan R, Roger JA (1995) Sb-Doped SnO2 Transparent Conducting Oxide from the Sol-Gel Dip-Coating Technique. Thin Solid Films 263 (1):37-41.

53. Terrier C, Chatelon JP, Roger JA (1997) Electrical and optical properties of Sb:SnO2 thin films obtained by the sol-gel method. Thin Solid Films 295 (1-2):95-100.

54. Lekshmy SS, Daniel GP, Joy K (2013) Microstructure and physical properties of sol gel derived $\mathrm{SnO} 2: \mathrm{Sb}$ thin films for optoelectronic applications. Appl Surf Sci 274:95-100.

55. Las WC, Dolet N, Dordor P, Bonnet JP (1993) Influence of Additives on the Electrical-Properties of Dense SnO2-Based Ceramics. J Appl Phys 74 (10):6191-6196.

56. Caldararu M, Thomas MF, Bland J, Spranceana D (2001) Redox processes in Sb-containing mixed oxides used in oxidation catalysis I. Tin dioxide assisted antimony oxidation in solid state. Appl Catal a-General 209 (1-2):383-390.

57. Barsan N, Weimar U (2001) Conduction model of metal oxide gas sensors. J Electroceramics 7 (3):143167.

58. Senoo Y, Kakinuma K, Uchida M, Uchida H, Deki S, Watanabe M (2014) Improvements in electrical and electrochemical properties of $\mathrm{Nb}$-doped $\mathrm{SnO} 2$-delta supports for fuel cell cathodes due to aggregation and Pt loading. Rsc Adv 4 (61):32180-32188. 